Commentary

\title{
It takes two $\mathrm{T}$ to shape immunity: emerging role for $\mathrm{T}$-type calcium channels in immune cells
}

\author{
Lubica Lacinova ${ }^{1}$ and Norbert Weiss ${ }^{2}$ \\ ${ }^{1}$ Institute of Molecular Physiology and Genetics, Slovak Academy of Sciences, Bratislava, Slovak Republic \\ ${ }^{2}$ Institute of Organic Chemistry and Biochemistry, Academy of Sciences of the Czech Republic, v.v.i., Prague, Czech Republic
}

Commentary to: Low-voltage-activated $\mathrm{Ca}_{\mathrm{v}} 3.1$ calcium channels shape T helper cell cytokine profiles (Immunity 2016, 782-794)

Key words: Calcium channel $-\mathrm{T}$-type channel $-\mathrm{Ca}_{\mathrm{v}} 3.1-$ Immune cells - Lymphocyte $-\mathrm{T}$ cells - Window current

T-type channels are defined as low-voltage-activated calcium channels, characterized by a low activation threshold that makes these channels perfectly suited to operate near the resting membrane potential of most electrically excitable cells. For instance, T-type channels play fundamentally important roles in shaping intrinsic neuronal excitability (Perez-Reyes 2003), and contribute to the pacemaker function in the heart (Cribbs 2010). Although T-type channels may be inactivated at rest and require brief periods of hyperpolarization to recover from inactivation, a significant fraction of channels may remain open supporting a "window current" that allows the passive influx of calcium inside the cell (Crunelli et al. 2005). The window calcium current may serve important physiological functions. For instance, passive calcium entry through T-type channels modulates the resting membrane potential of nerve cells (Dreyfus et al. 2010). A role for the window current in the differentiation of myoblasts has also been documented (Bijlenga et al. 2000). In addition, steady-state entry of calcium through T-type channels may also play important roles in non-excitable cells per se. Indeed, the expression of T-type channels is not restricted to excitable cells and has been documented in a number of non-neuronal tissues including fibroblasts (Peres et al. 1988), lung (Zhou and Wu 2006), liver (Li et al. 2009), pancreas (Braun et al. 2008), kidney (Hayashi et al. 2007), and also in female (Ohkubo et al. 2005) and male reproductive tissues (Darszon et al. 2006), where T-type

Correspondence to: Norbert Weiss, Institute of Organic Chemistry and Biochemistry, Academy of Sciences of the Czech Republic, v.v.i., Prague, Czech Republic

E-mail: weiss@uochb.cas.cz channels may play complex yet fundamentally important (patho)physiological functions. The window current supported by T-type channels may also be of direct relevance to an interesting recent study by Wang and colleagues (Wang et al. 2016) published in Immunity, on the role of T-type channels in the immune system.

In lymphocytes, calcium entry though store operated calcium channels (SOC) represents the major pathway for intracellular calcium elevation, which controls a number of cellular processes including development, survival, proliferation, and activation (Oh-hora and Rao 2008). For instance, the influx of calcium through calcium release-activated calcium channels (CRAC) initiates $\mathrm{T}$ cell antigen receptor (TCR) leading to the activation of T cells. However, while CRAC channels represent the main pathway for calcium entry into T lymphocytes, a number of other calcium permeable ion channels are expressed at the surface of $\mathrm{T}$ cells, including voltage-gated calcium channels (Badou et al. 2013). However, the molecular mechanisms by which these channels are mobilized, and their relative contribution to $\mathrm{T}$ cell physiology remain incompletely understood. Using a combination of molecular, biochemical, and electrophysiological approaches, Wang and colleagues demonstrated that $\mathrm{Ca}_{\mathrm{v}} 3.1$ T-type channels are functionally expressed at the surface of $\mathrm{T}$ cells with the typical characteristic of T-type currents described in neuronal tissues. To assess the functional role of T-type channels in T cells, the authors performed a number of cellular assays and found no implication of T-type channels in TCR-initiated signaling, or in the development and maturation of T cells. In contrast, using an in vivo model of experimental autoimmune encephalomyelitis (EAE), the authors showed that mice deficient in $\mathrm{Ca}_{\mathrm{v}} 3.1$ (constitutive 


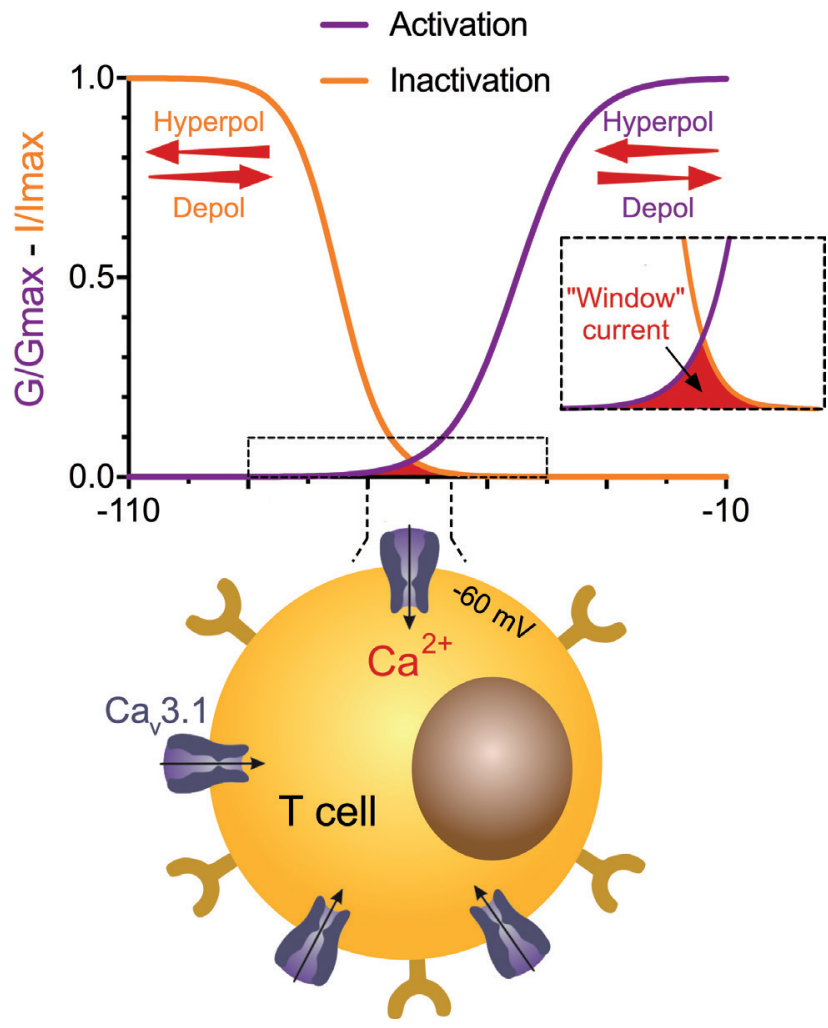

Figure 1. Mechanism of T-type channel-dependent calcium entry in $\mathrm{T}$ cells. The overlapping between the activation (purple) and steady-state inactivation curves (orange) of T-type channels generates a "window" current (red area) for passive calcium entry at typical resting membrane potential of $\mathrm{T}$ cells. Alteration of the voltage-dependence of activation or inactivation (hyperpolarization or depolarization) by pharmacological modulators of T-type channels or pathological mutations will affect the "window" current (increase or decrease as depicted by the red arrows), which eventually may alter calcium signaling in T cells.

$\mathrm{Ca}_{\mathrm{v}} 3.1$ knock-out) display significant resistance to EAE induction, evidenced by a delayed paresis, reduced weight loss, and reduced inflammation and demyelination of the spinal cord. To further assess the contribution of lymphocytic T-type channels, the authors used a mouse with restricted deletion of $\mathrm{Ca}_{\mathrm{v}} 3.1$ in $\mathrm{T}$ cells and observed a similar protective phenotype, demonstrating the essential contribution of lymphocytic $\mathrm{Ca}_{\mathrm{v}} 3.1$ channels. Analysis of infiltrating cells in the central nervous system (CNS) reveled that the EAE resistance is likely to be mediated by a reduced production of granulocyte-macrophage colony stimulating factor (GMCSF) by CNS-infiltrating Th1 and Th17 cells. Finally, using in vitro assays, the authors further reveled that $\mathrm{Ca}_{\mathrm{v}} 3.1$ contributes to intracellular calcium elevation during Th17 cell polarization, which may support the production of GM-CSF by driving nuclear translocation of the calcium-dependent transcription factor NFAT.
The novel and important findings of Wang and colleagues raise interesting question about the functioning of T-type channels in immune cells. Considering that lymphocytes are not excitable cells per se, it is most likely that calcium entry through T-type channels occurs within the window current (Figure 1). Consistent with this notion, the resting membrane potential of lymphocytes, measured using fluorescent probes, is believed to range between $-60 \mathrm{mV}$ and $-55 \mathrm{mV}$ (Rink et al. 1980), which is compatible with the voltage window for passive influx of calcium through T-type channels. Interestingly, a number of pharmacologically active molecules on T-type channels modulate the voltage-dependence of activation or inactivation of the channel, thus altering the window current. For instance, the anesthetic alcohol 1-octanol significantly hyperpolarizes the steady-state inactivation of $\mathrm{Ca}_{\mathrm{v}} 3.2$ channels, reducing the window current (Joksovic et al. 2010). In addition, T-type channels that may represent a potential co-target for antidepressants (Pavlovicova et al. 2015) are sensitive to the widely used antidepressant fluoxetine $\left(\right.$ Prozac $\left.^{\circledast}\right)$ and its metabolite norfluoxetine, evidenced by a shift of the steady-state inactivation of all three $\mathrm{Ca}_{\mathrm{v}} 3$ isoforms towards more negative membrane potentials, and thereby markedly reducing the window current (Traboulsie et al. 2006). A similar hyperpolarizing shift was also reported for neuroleptics pimozide, penfluoridol, flunarizine and haloperidol (Santi et al. 2002). In addition, Todorovic and Lingle reported a pronounced voltage-dependent action of mibefradil on $\mathrm{Ca}_{\mathrm{v}} 3.2$ T-type calcium currents in dorsal root ganglion neurons, with the steady-state inactivation curve being shifted by about -20 $\mathrm{mV}$ that may result in a complete disappearance of the window current (Todorovic and Lingle 1998). T-type channels are also sensitive to a number of endogenous agents. For instance, arachidonic acid potently shifts the steady-state inactivation of $\mathrm{Ca}_{\mathrm{v}} 3.2$ channels, eliminating the window current (Zhang et al. 2000). Considering that arachidonic acid is used in a number of anabolic bodybuilding supplements, alteration of the immune response may represent a side effect of these products.

In addition to pharmacological modulation of T-type channels that may have important consequences on the immune response, alteration of T-type channel activity has been linked to a number of genetic disorders caused by mutation in the genes encoding for the channel protein. For instance, a number of mutations in the gene $C A C N A 1 H$ encoding for $\mathrm{Ca}_{\mathrm{v}} 3.2$ channels associated with childhood absence epilepsy either hyperpolarize the voltage-dependence of activation of the channel, or depolarize the steady-state of inactivation, reducing the window current (Khosravani et al. 2004). Genetic alteration of $\mathrm{Ca}_{\mathrm{v}} 3.2$ channel gating was also reported in chronic pain (Souza et al. 2016) and amyotrophic lateral sclerosis (Rzhepetskyy et al. 2016), where the window current is likely to be altered. Similarly, altered gating of $\mathrm{Ca}_{\mathrm{v}} 3.1$ 
channels by mutations associated with cerebellar ataxia has been documented (Coutelier et al. 2015, Morino et al. 2015). Considering that modulation of immunity has recently emerged as a new target for the treatment of a number of neuronal disorders including some forms of epilepsy (Yu et al. 2013), it may be important to reconsider these mutations in the context of the immune response.

Overall, the findings of Wang and colleagues shed light on the presumable implication of T-type channels in the shaping of the immune response. Importantly, alteration of the window current by clinically relevant T-type channel blockers should be taken seriously when designing new therapeutic molecules as it may have important adverse effects on the immune response. On the other hand, FDA-approved T-type channel blockers could conceivably be repurposed for the treatment of immune disorders.

Acknowledgements. Work in the Weiss laboratory is supported by the Czech Science Foundation (grant 15-13556S), the Czech Ministry of Education Youth and Sports (grant 7AMB15FR015), and the Institute of Organic Chemistry and Biochemistry (IOCB). Work in the Lacinova laboratory is supported by grant VEGA 2/0107/16 and by the Slovak Research and Development Agency under the contract No. APVV-15-0388.

\section{References}

Badou A., Jha M. K., Matza D., Flavell R. A. (2013): Emerging roles of L-type voltage-gated and other calcium channels in $\mathrm{T}$ lymphocytes. Front. Immunol. 4, 243 http://dx.doi.org/10.3389/fimmu.2013.00243

Bijlenga P., Liu J. H., Espinos E., Haenggeli C. A., Fischer-Lougheed J., Bader C. R., Bernheim L. (2000): T-type alpha 1H Ca2+ channels are involved in $\mathrm{Ca} 2+$ signaling during terminal differentiation (fusion) of human myoblasts. Proc. Natl. Acad. Sci. USA 97, 7627-7632 http://dx.doi.org/10.1073/pnas.97.13.7627

Braun M., Ramracheya R., Bengtsson M., Zhang Q., Karanauskaite J., Partridge C., Johnson P. R., Rorsman P. (2008): Voltagegated ion channels in human pancreatic beta-cells: electrophysiological characterization and role in insulin secretion. Diabetes 57, 1618-1628 http://dx.doi.org/10.2337/db07-0991

Coutelier M., Blesneac I., Monteil A., Monin M. L., Ando K., Mundwiller E., Brusco A., Le Ber I., Anheim M., Castrioto A., et al. (2015): A recurrent mutation in CACNA1G alters Cav3.1 T-type calcium-channel conduction and causes autosomaldominant cerebellar ataxia. Am. J. Hum. Genet. 97, 726-737 http://dx.doi.org/10.1016/j.ajhg.2015.09.007

Cribbs L. (2010): T-type calcium channel expression and function in the diseased heart. Channels (Austin) 4, 447-452 http://dx.doi.org/10.4161/chan.4.6.12870

Crunelli V., Tóth T. I., Cope D. W., Blethyn K., Hughes S. W. (2005): The ,window' T-type calcium current in brain dynamics of different behavioural states. J. Physiol. 562, 121-129 http://dx.doi.org/10.1113/jphysiol.2004.076273
Darszon A., López-Martínez P., Acevedo J. J., Hernández-Cruz A., Trevi-o C. L. (2006): T-type Ca2+ channels in sperm function. Cell. Calcium 40, 241-252 http://dx.doi.org/10.1016/j.ceca.2006.04.028

Dreyfus F. M., Tscherter A., Errington A. C., Renger J. J., Shin H. S., Uebele V. N., Crunelli V., Lambert R. C., Leresche N. (2010): Selective T-type calcium channel block in thalamic neurons reveals channel redundancy and physiological impact of $\mathrm{I}(\mathrm{T})$ window. J. Neurosci. 30, 99-109 http://dx.doi.org/10.1523/JNEUROSCI.4305-09.2010

Hayashi K., Wakino S., Sugano N., Ozawa Y., Homma K., Saruta T. (2007): Ca2+ channel subtypes and pharmacology in the kidney. Circ. Res. 100, 342-353 http://dx.doi.org/10.1161/01.RES.0000256155.31133.49

Joksovic P. M., Choe W. J., Nelson M. T., Orestes P., Brimelow B. C., Todorovic S. M. (2010): Mechanisms of inhibition of T-type calcium current in the reticular thalamic neurons by 1-octanol: implication of the protein kinase $\mathrm{C}$ pathway. Mol. Pharmacol. 77, 87-94 http://dx.doi.org/10.1124/mol.109.059931

Khosravani H., Altier C., Simms B., Hamming K. S., Snutch T. P., Mezeyova J., McRory J. E., Zamponi G. W. (2004): Gating effects of mutations in the Cav3.2 T-type calcium channel associated with childhood absence epilepsy. J. Biol. Chem. 279, 9681-9684 http://dx.doi.org/10.1074/jbc.C400006200

Li Y., Liu S., Lu F., Zhang T., Chen H., Wu S., Zhuang H. (2009): A role of functional T-type Ca2+ channel in hepatocellular carcinoma cell proliferation. Oncol. Rep. 22, 1229-1235

Morino H., Matsuda Y., Muguruma K., Miyamoto R., Ohsawa R., Ohtake T., Otobe R., Watanabe M., Maruyama H., Hashimoto K., Kawakami H. (2015): A mutation in the low voltage-gated calcium channel CACNA1G alters the physiological properties of the channel, causing spinocerebellar ataxia. Mol. Brain 8, 89 http://dx.doi.org/10.1186/s13041-015-0180-4

Oh-hora M., Rao A. (2008): Calcium signaling in lymphocytes. Curr. Opin. Immunol. 20, 250-258 http://dx.doi.org/10.1016/j.coi.2008.04.004

Ohkubo T., Inoue Y., Kawarabayashi T., Kitamura K. (2005): Identification and electrophysiological characteristics of isoforms of T-type calcium channel Ca(v)3.2 expressed in pregnant human uterus. Cell Physiol. Biochem 16, 245-254 http://dx.doi.org/10.1159/000089850

Pavlovicova M., Lacinova L., Dremencov E. (2015): Cellular and molecular mechanisms underlying the treatment of depression: focusing on hippocampal G-protein-coupled receptors and voltage-dependent calcium channels. Gen. Physiol. Biophys. 34, 353-366

Peres A., Sturani E., Zippel R. (1988): Properties of the voltagedependent calcium channel of mouse Swiss 3T3 fibroblasts. J. Physiol. 401, 639-655 http://dx.doi.org/10.1113/jphysiol.1988.sp017184

Perez-Reyes E. (2003): Molecular physiology of low-voltage-activated t-type calcium channels. Physiol. Rev. 83, 117-161 http://dx.doi.org/10.1152/physrev.00018.2002

Rink T. J., Montecucco C., Hesketh T. R., Tsien R. Y. (1980): Lymphocyte membrane potential assessed with fluorescent probes. Biochim. Biophys. Acta 595, 15-30 http://dx.doi.org/10.1016/0005-2736(80)90243-6 
Rzhepetskyy Y., Lazniewska J., Blesneac I., Pamphlett R., Weiss N. (2016): CACNA1H missense mutations associated with amyotrophic lateral sclerosis alter Cav3.2 T-type calcium channel activity and reticular thalamic neuron firing. Channels (Austin) (in press) http://dx.doi.org/10.1080/19336950.2016.1204497

Santi C. M., Cayabyab F. S., Sutton K. G., McRory J. E., Mezeyova J., Hamming K. S., Parker D., Stea A., Snutch T. P. (2002): Differential inhibition of T-type calcium channels by neuroleptics. J. Neurosci. 22, 396-403

Souza, I. A., M. A. Gandini, M. M. Wan, and G. W. Zamponi (2016): Two heterozygous Cav3.2 channel mutations in a pediatric chronic pain patient: recording condition-dependent biophysical effects. Pflügers Arch. 468, 635-642 http://dx.doi.org/10.1007/s00424-015-1776-3

Todorovic S. M., Lingle C. J. (1998): Pharmacological properties of T-type Ca2 + current in adult rat sensory neurons: effects of anticonvulsant and anesthetic agents. J. Neurophysiol. 79, 240-252

Traboulsie A., Chemin J., Kupfer E., Nargeot J., Lory P. (2006): T-type calcium channels are inhibited by fluoxetine and its metabolite norfluoxetine. Mol. Pharmacol. 69, 1963-1968 http://dx.doi.org/10.1124/mol.105.020842

Wang H., Zhang X., Xue L., Xing J., Jouvin M. H., Putney J. W., Anderson M. P., Trebak M., Kinet J. P. (2016): Low-voltageactivated CaV3.1 calcium channels shape Thelper cell cytokine profiles. Immunity 44, 782-794 http://dx.doi.org/10.1016/j.immuni.2016.01.015

Yu N., Liu H., Di Q. (2013): Modulation of immunity and the inflammatory response: A new target for treating drug-resistant epilepsy. Curr. Neuropharmacol. 11, 114-127 http://dx.doi.org/10.2174/1570159x11311010014

Zhang Y., Cribbs L. L., Satin J. (2000): Arachidonic acid modulation of alpha1H, a cloned human T-type calcium channel. Am. J. Physiol. Heart Circ. Physiol. 278, H184-193

Zhou C., Wu S. (2006): T-type calcium channels in pulmonary vascular endothelium. Microcirculation 13, 645-656 http://dx.doi.org/10.1080/10739680600930289

Received: August 3, 2016

Final version accepted: August 3, 2016 